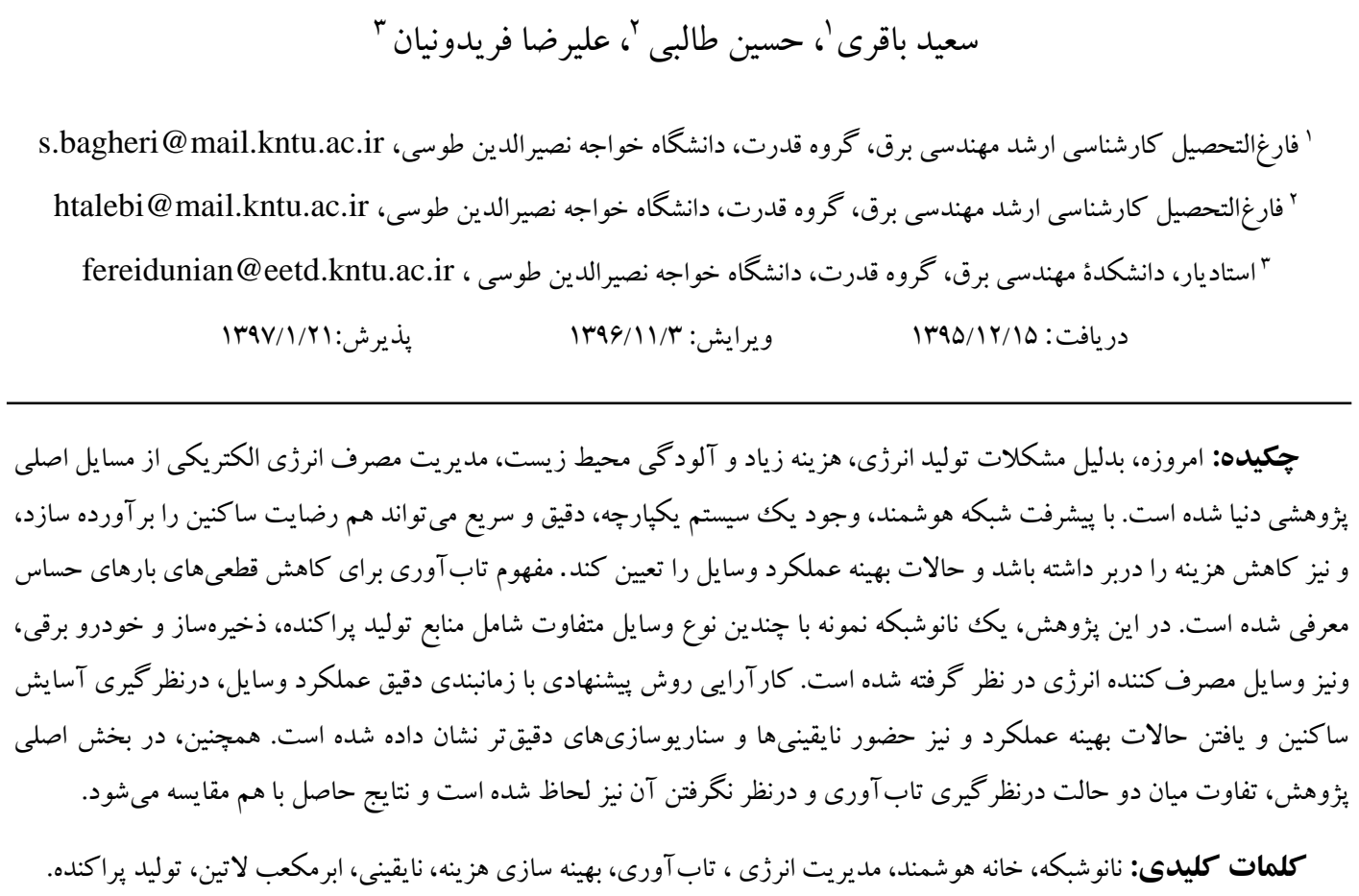

\title{
Resilient, Comfort and Economic Operation of Smart Nanogrid
}

\section{Saeed Bagheri and Hossein Talebi, Alireza Fereidunian}

\begin{abstract}
Nowadays, the management of power consumption has been one of the main concerns for researchers, because of energy generation problems, high cost and environment pollutions. An integrated, fast and accurate system can earn satisfaction of occupants and also cost reduction. Some loads are very vulnerable to natural disasters, thus this interruptions are costly for customers. The resiliency concept is introduced accordingly. The model presented in this research is a Nanogrid, equipped with DGs, batteries and electric vehicle, and power consumer. This research devotes an effort to optimize household energy cost, occupants comfort and Nanogrid resiliency with optimal scheduling of all elements considering uncertainty of distributed energy. If needed, utility can reduce potential peaks occurrence in grid, too. Finally, the performance of the method is discussed by simulation on a typical model. Simulation results under different pricing and weather modes, show effectiveness of proposed model on reducing the quantities of each considered cost functions.
\end{abstract}

Keywords: Nanogrid, Resilience, energy management, renewable energy sources, uncertainty, stochastic programming. 


\begin{tabular}{|c|c|c|c|}
\hline$t^{O D}$ & تعداد بازه عملكرد وسيله بعد از آغاز به كار & & شرح اختصار \\
\hline$t_{j}^{\text {finish }}$ & بازه زمانى يايان عملكرد وسيله زام & LHS & روش نمونهبردارى ابرمكعب لاتين \\
\hline$O S_{t, j}$ & متغير باينرى وضعيت عملكرد وسيله زام در بازه ltم & MILP & برنامهريزى خطى عدد صحيح مختلط \\
\hline$P_{t, j}^{s c h}$ & تو توان مصرفى وسيله زام در بازه زمانى اt م & EEMS & سيستم مديريت انرزى خبره \\
\hline$P_{t}^{\text {demand.sch }}$ & كل توان مصرفى وسايل كنترل زمانى در بازه الم & RTP & قيمت كذارى بلادرنگك \\
\hline$D T R_{j}$ & 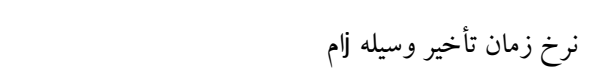 & SOC & وضعيت شارز (ميزان انرزى ذخيره شده) \\
\hline$\rho$ & بارامتر تأخير & PEV & 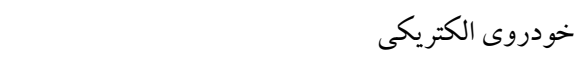 \\
\hline$\theta_{t}^{a m b}, \theta_{t}^{r o o m}$ & دماى اتاق و هواى محيط در بازه زمانى الم & PSO & بهينه سازى ازدحام ذرات \\
\hline$\theta_{t}^{\text {set,heater }}$ & دماى تنظيم سيستم سرمايش و گرمايش در بازه زمانى ام & DTR & 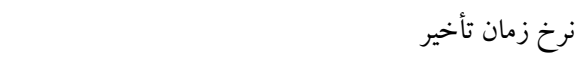 \\
\hline$\theta_{t}^{\text {set,cooler }}$ & 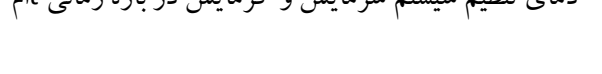 & EENS & انتظار انرزى تأمين نشده \\
\hline $\boldsymbol{\theta}_{\text {cooler }}^{g}, \theta_{\text {marg in }}$ & مقدار حاشيه اى دماى عملكرد و ثابت كاهش دما & & شرح علامت \\
\hline$O S_{t}^{\text {cooler }}$ & وضعيت عملكرد سيستم سرمايش در بازه زمانى ام & $P_{\text {thr. }}^{\text {peak }}$ & مقدار آستانه بيكك تقاضا از شبكه \\
\hline \multirow[t]{2}{*}{$k_{\text {human }}, k_{\text {th }}^{\text {room }}$} & ثابت ترموديناميكى اتاق و ثابت تبادل گرمايى بين انسان & $\delta$ & طول بازمى زمانى \\
\hline & و محيط & $p d P$ & قيمت هر كيلووات ساعت انرزى دريافتى از شبكه بيشتر \\
\hline$n_{\text {occupants }}(t)$ & تعداد افراد حاضر در اتاق در بازه زمانى lt & & از مقدار آستانه \\
\hline$k_{\text {cooler }}^{\text {eff. }}$ & ضريب اثر كذارى دمايى سيستم سرمايش & $v_{a w}, v_{m}$ & 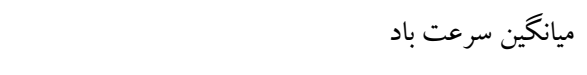 \\
\hline$P_{t}^{\text {demand,cooler }}$ & توان دريافتى سيستم سرمايش در بازه زمانى ام & $v_{c o}, v_{c i}$ & 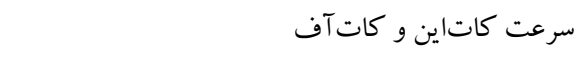 \\
\hline$P^{\text {cooler }}$ & توان الكتريكى مصرفى در سيستم سرمايش & $v_{a w}, v_{r}$ & سرعت نامى و سرعت اعمال شده به توربين بادى \\
\hline NOC & تابع هزينه عملكرد نانوشبكه & $P_{w}(v)$ & Vو توان خروجى توربين بادى به ازاى سرعت باد v \\
\hline$m^{p v}, m^{\text {batt }}$, & هزينه نغهارى توربين بادى، سلول خورشيدى و باترى & $P_{P V}(s i)$ & 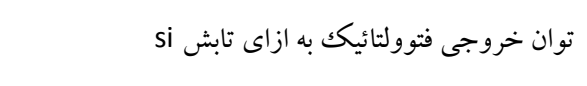 \\
\hline$m^{w t}$ & & $\eta^{P V}$ & 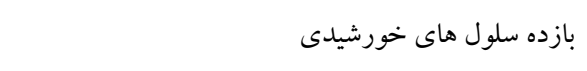 \\
\hline $\mathrm{D}_{\mathrm{t}}^{\mathrm{PEV}}$ & مسافت طى شده توسط خودرو برقى (كيلومتر) & $S^{P V}$ & مساحت كل فتوولتائيك \\
\hline \multirow[t]{2}{*}{$\mathrm{C}_{\mathrm{PEV}}$} & انرزى مصرف شده در خودروى الكتريكى به ازاى هر & $P_{\text {rated }}$ & 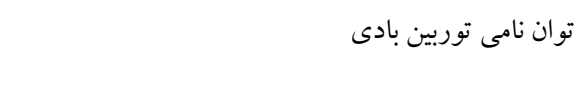 \\
\hline & 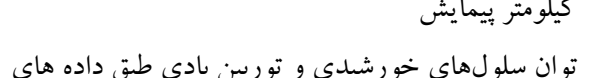 & $\eta_{P E V}^{c h}, \eta_{P E V}^{d c h}$ & بازده شارز و دشارز خودروى الكتريكى \\
\hline $\boldsymbol{P}_{t}^{p v}, P_{t}^{w t}$ & بيش بينى & $S O C_{t}^{P E V}$ & انرزى ذخيره شده در خودروى الكتريكى در بازه tlم \\
\hline$q_{t} b_{t}$ & 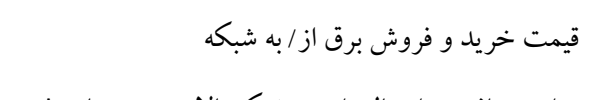 & $\begin{array}{l}P_{t}^{P E V, c h} \\
P_{t}^{P E V, d c h}\end{array}$ & توان شارز و دشارز خودروى الكتريكى در بازه زمانى lt \\
\hline \multirow{2}{*}{$P_{t}^{g r i d, b u y}$} & توان دريافتى و ارسالى از به شبكه بالادست در بازه t & $P_{t}^{P E V}$ & ت توان شارز/دشارز خودروى الكتريكى \\
\hline & & $P_{t}^{\text {demand.non_sch }}$ & توان مصرفى خودروى الكتريكى توسط لوازم خانكى غير \\
\hline s & شماره سناريو & & قابل كترل زمانى در بازه أlt \\
\hline \multirow[t]{2}{*}{$P_{s, t}^{p v}, P_{s, t}^{w t}$} & توان خروجى از توربين بادى و سلول خورشيدى در بازه & $t_{j}^{\text {start }}$ & بازه زمانى آغاز به كار وسيله زام \\
\hline & ام ام از سناريوى Sام & j & شاخص نشان دهنده هر وسيله \\
\hline \multirow[t]{2}{*}{$\pi_{s}$} & احتمال سناريوى Sام & $t^{E S t}$ & زودترين بازه زمانى آغاز به كار \\
\hline & & $t^{L F}$ & ديرترين بازه زمانى بايان عملكرد \\
\hline
\end{tabular}


نمودى از تاب آور كردن سيستم مىباشد. اين مفهوم وابسته به توليد، تقاضا،

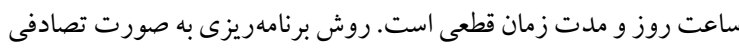

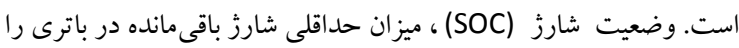

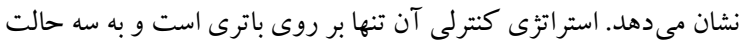
در نظر گرفته شده است. حالت اول باترى تا آخرين لحظه دشارز شود و و شارز آن تنها با توليد محلى باشد. در حالت دوم وقتى شبكه متصل است

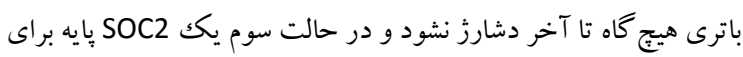

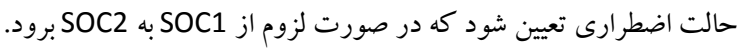
در [4] آناليز تاثير مديريت انرزى در مو اقع خروج توليد، در صورت دور اتصال خودرو به خانه هو شمند كار شده است. استر اتزى استفاده شده مد عملكرد

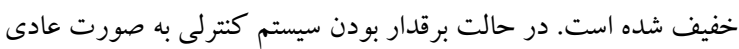

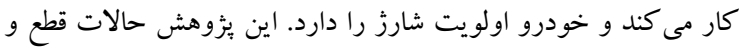

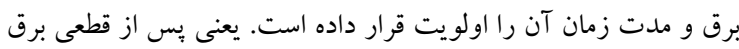

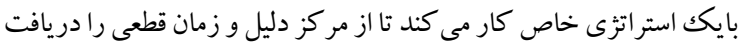

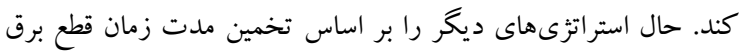

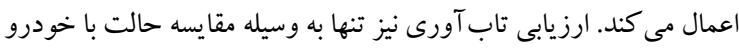
برقى و بدون خودرو برقى انجام شده است. به گَونهاى كه با تحليل نمودار

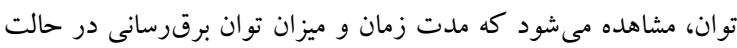
جزيرهاى با كمى حساسيت بهبود يافته است كه اين خود نمودى از تابآورى در نانوشبكه مى باشد.

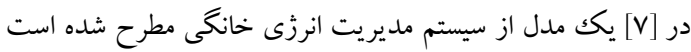
كه استراتزى مديريتى را با هدف افزايش تاب آورى نشان مىدهد.

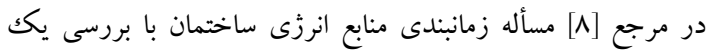
ساختمان كم انرزى كاربردى مقايسه شدهاست. تابع هدف آن، كمينه كردن

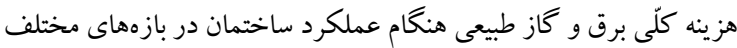
زمانى مىباشد درحالى كه قيد تعادل انرزى و قيود عملكرد بي بيجيده وسايل

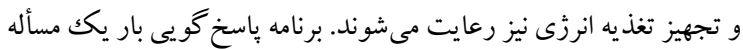

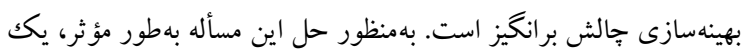

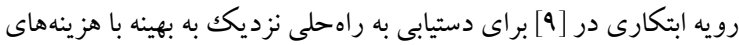

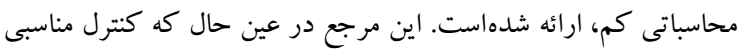

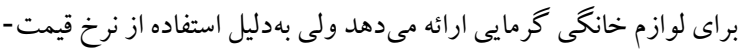

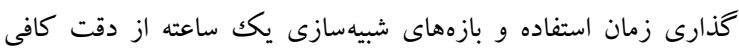

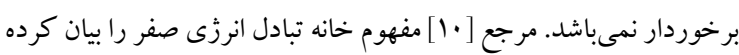

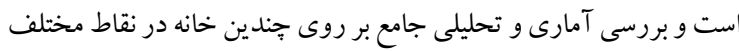

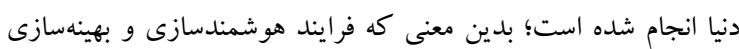

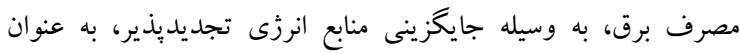

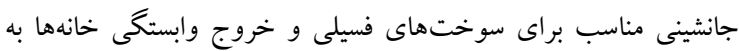
شبكه برق را بيان مى كند و تاثير حضور اين مفهوم را به خوبى نشان مى دهدئ.

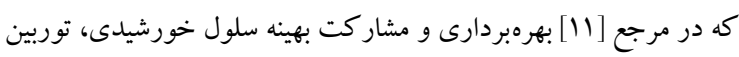

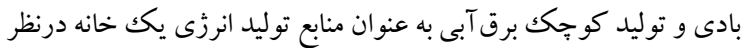

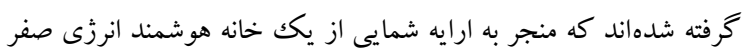

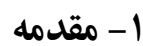

ساختمانهاى تجارى و مسكونى بيش از •هـ\% مصرف انرزى الكتريكى ارويا را به خود اختصاص مى دهندكه عموما داراى بازده بيايين

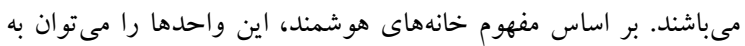
كرههاى يكك شبكه هوشمند تبديل كرد كه بخش جشم گيرى از انرزى هـ

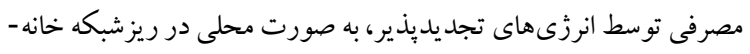

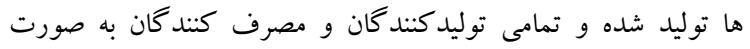

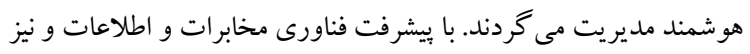

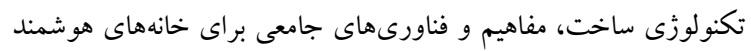

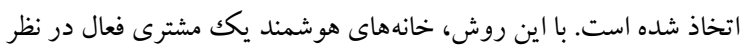

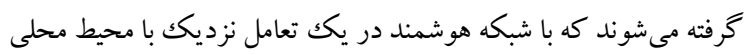

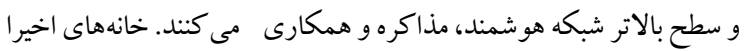

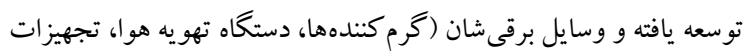

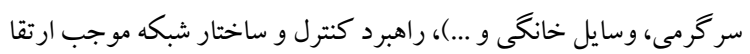
بازده انرزى و بهبود مديريت ريزشبكه برق محلى ونى و شبكه دوردست از

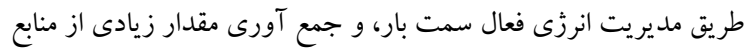

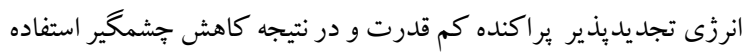

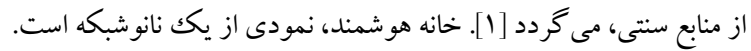
با توجه به تعاريف نانوشبكه و دستاوردهاى اخير در اين زمينه، خانههاى

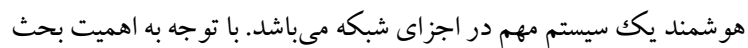

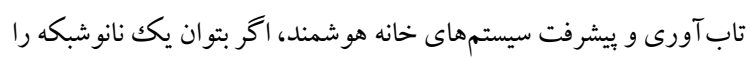

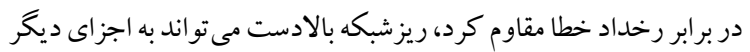

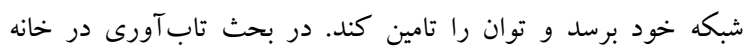

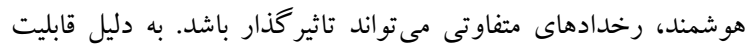

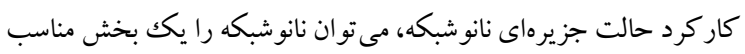

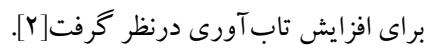

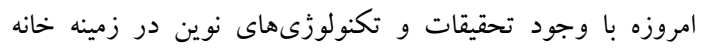

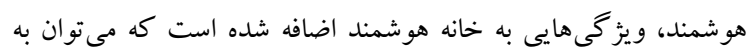
وسيله آن، زيرساختهاى مناسب را براى سيستمهاى كنترلى به به منظور

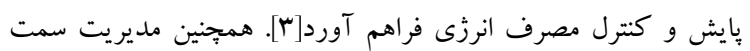

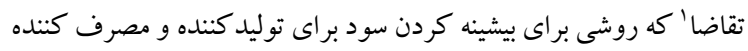

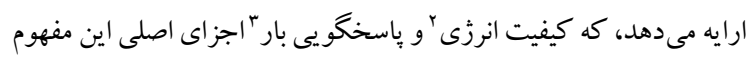

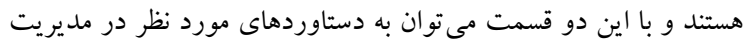

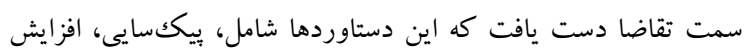
بايايى و كاهش هزينه مىشود [F]. يُروهشهاى مختلفى در زمينه تاب آورى و نانوشبكه انجام شده است

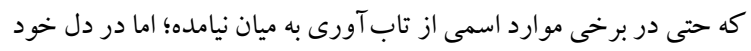

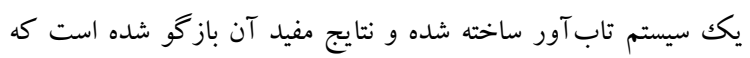
همخى در حالات اضطرار بررسى شدهاند.

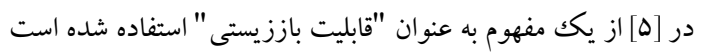

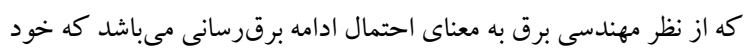


قرار گيرى تاب آورى در مساله انجام شده است. تفاوت اصلى اين مقاله با ساير مقالات، درنظر گيرى تابآورى از سطح جزئى كه همان نانوشبكه

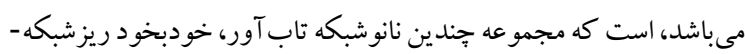

$$
\text { اى تاب آور را در يى دارد. }
$$

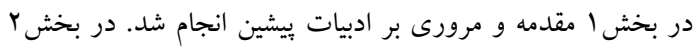

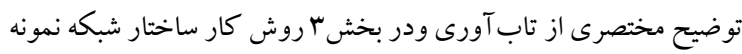

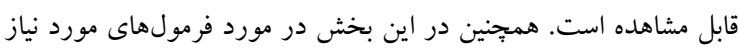

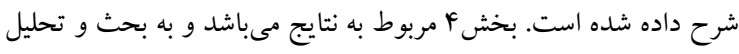

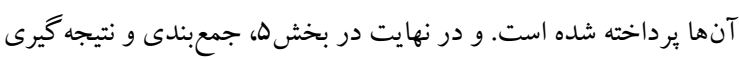

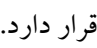

\section{r- تاب آورى'}

خاموشىهاى گسترده با احتمال بسيار بايينى امكان رخ دادن دارند اما

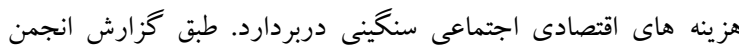
اقتصادى كاخ سفيد در امريكا، بيشترين دليل قطعى برق در اين كشور بر بر دردئ اثر حوادث جوى است. مطالعات نشان مى دهد ضرر مربوط به مشكلات

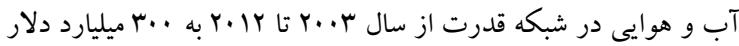

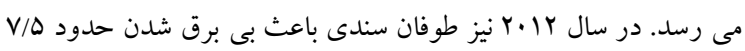

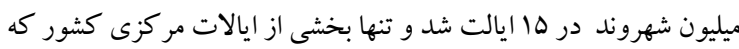

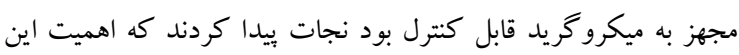

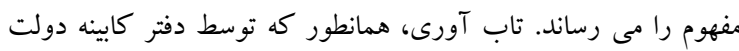

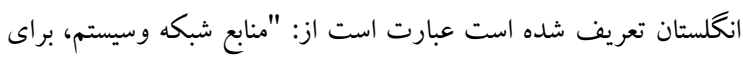

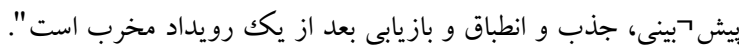

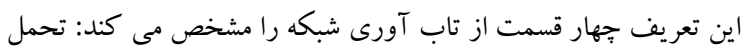

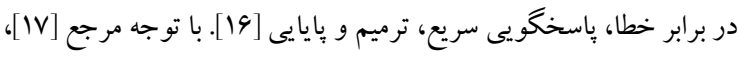

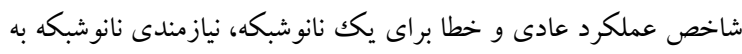

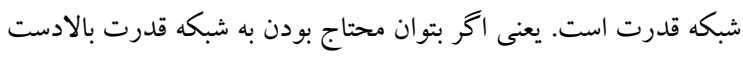

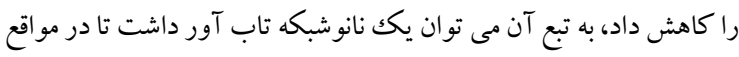

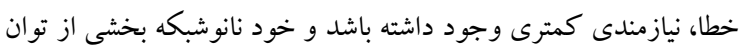

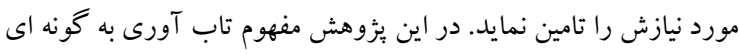

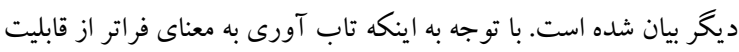

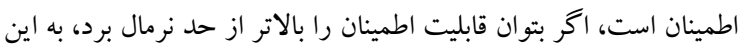

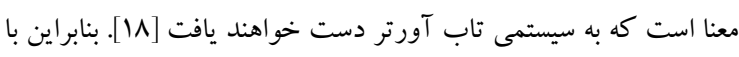
توجه به احتمال قطعى برق از شبكه بالادست، اخر بتوان نيازمندى به سيستم بالادست را كاهش داد مى توان سيستم را تاب آور كرد.

در مفهوم تاب آورى، وابستكى شديد به عواقب يكك حادثه، تطبيق

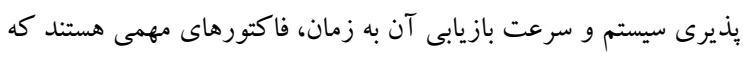

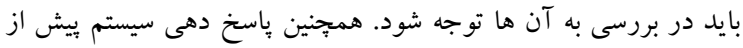

كارامد، جه از نظر عدم آلودگى و جهه از نظر هز ينه را به خوبى به نمايش

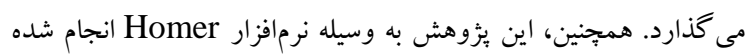

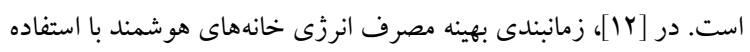
از يك روش برنامهريزى خطى عدد صحيح مختلط (MILP) مورد

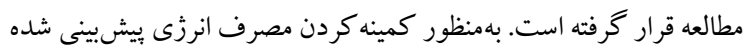

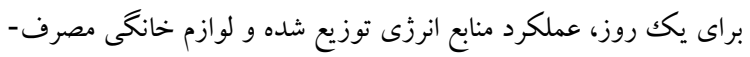

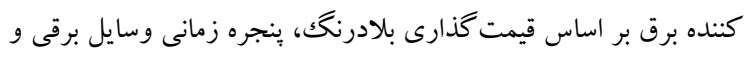

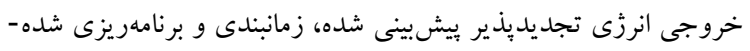

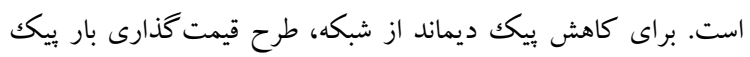

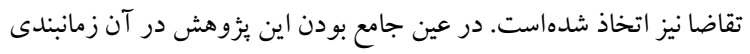

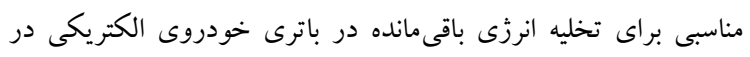

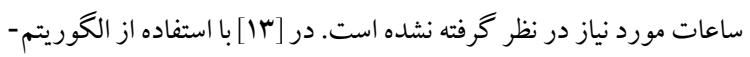

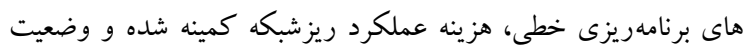

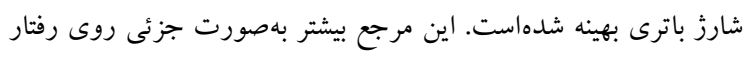

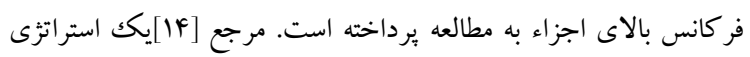

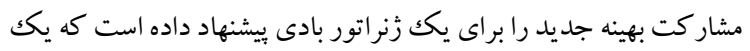

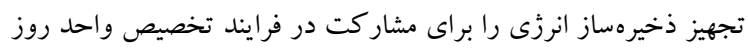

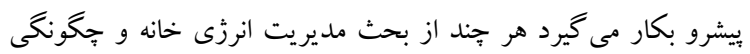

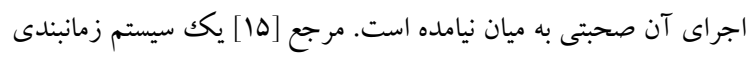

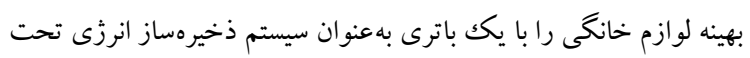

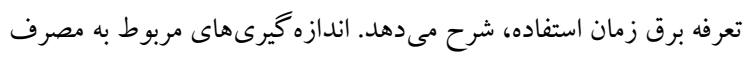

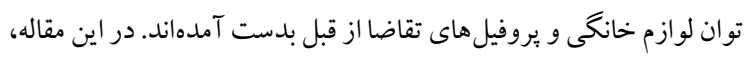

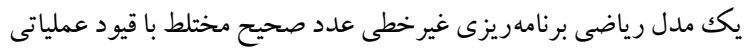
كاربردى تر براى زمانبندى باترى، فرموله و حل شدهاست فرئ در نهايت نتايج

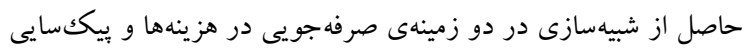

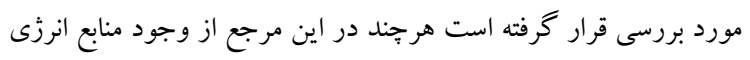
باد و خورشيد در خانه بهره گرفته نشده است.

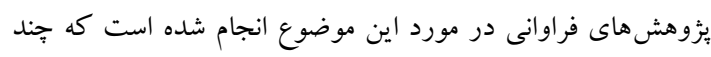

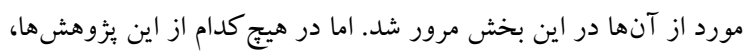

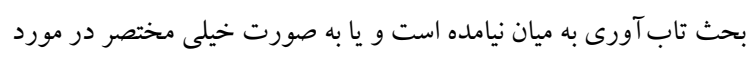

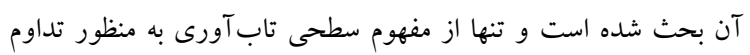

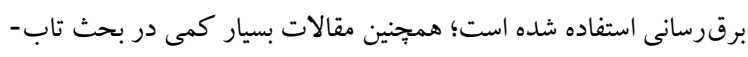

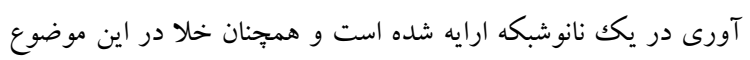
احساس مى شود. اين بثروهش، بحث تاب آورى را در سطح نانوشبكه بيان كرده است. در

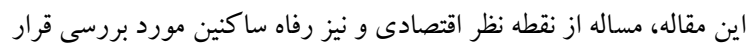
مى گيرد. نكته قابل توجه اين است كه بحث تاب آور بودن خانه نيز توامان

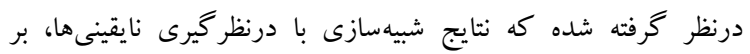

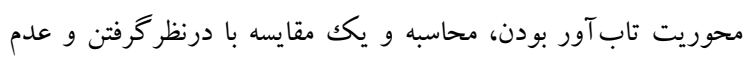


است سيستم ذخيرهسازى انرزى را شارز يا دشارز نمايد. شكل(Y) مدل مفهومى اين برزوهش را ارايه مىدهد.

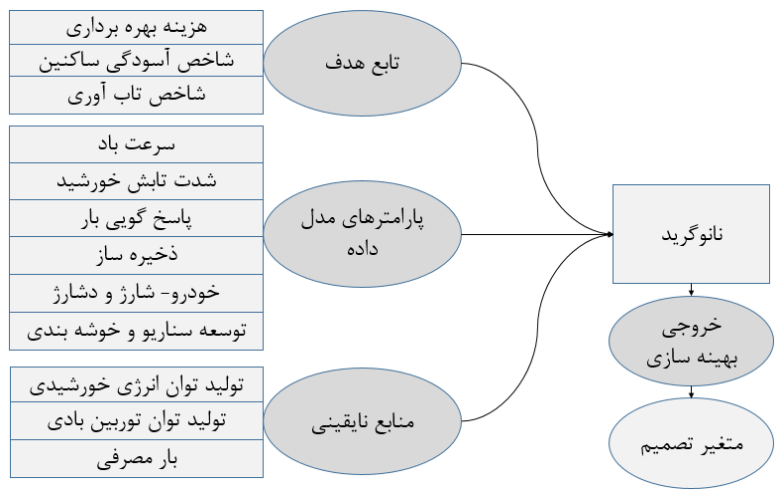

شكل r: مدل مفهومى كار مطالعاتى اين مقاله

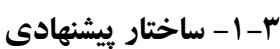
اجزاى نانوشبكهاى كه در اين يُزوهش مورد مطالعهادئه قرار گرفته است، بهورت شكل ب مىباشد.

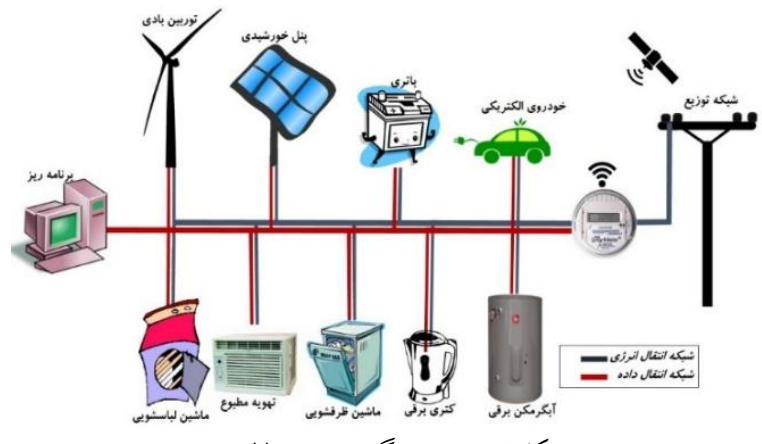

شكل ז: اجزاى نانو گريد مورد مطالعه

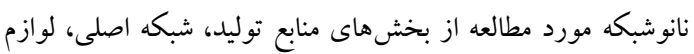
خانكى و كنترل كننده تشكيل شده است. كنترل كننده نانوشبكه، وظيفه

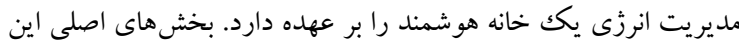

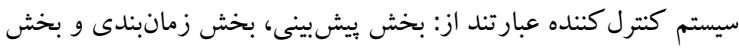

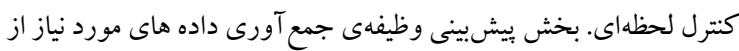

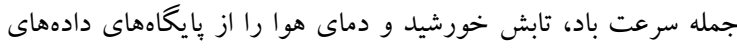

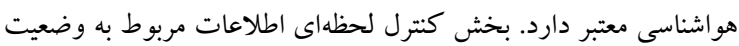
عملكرد ساير اجزاء را از طريق سنسور ها و شبكه مخابر اتى در اختيار سيستم

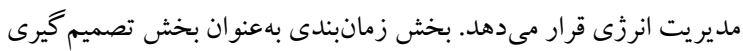
سيستم مديريت انرزى عمل مى كند.

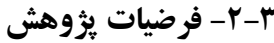

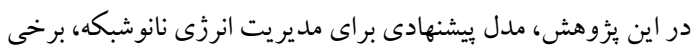

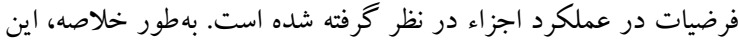

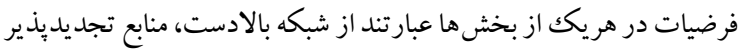

اختلال، بـ از آن و در طول حادثه مهم است [19-1Y]]. در شكل ا روند تاب آورى در يك سيستم قدرت مشخص شده است. شاخص

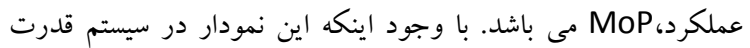
تعريف شده است، اما مى توان روى هر سيستمى اجرا كرد. اما براى ظاجر ایى اين رابطه، بسته به نوع مطالعه، MoP مو رد نظر بايد انتخاب شود دود.

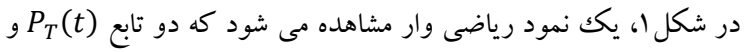
مشخص شده اند كه به ترتيب تابع مقدار شاخص عملكرد در حالت عادى و در حالت خطا مى باشد. در رابطه (1)، (t) اندازه گيرى تاب آورى مى باشد.

$$
R(T)=\frac{\int_{0}^{T} P_{R}(t) d t}{\int_{0}^{T} P_{T}(t) d t}
$$

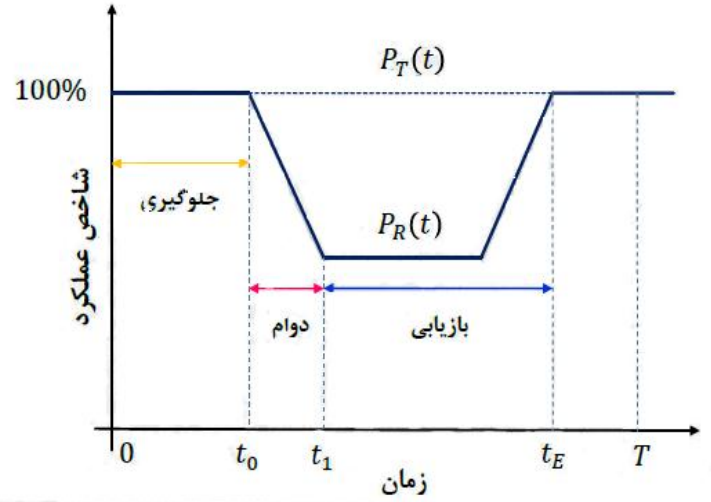

شكل ا: نمودار مربوط به شاخص تابحآورى[Yr].

با توجه مرجع [rr]، شاخص عملكرد عادى و خطا براى يكك نانوشبكه، نيازمندى نانوشبكه به شبكه قدرت است. يعنى اكر بتوان محتاج

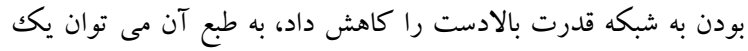

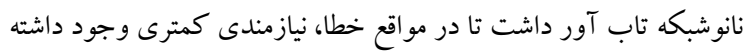
باشد و خود نانوشبكه بخشى از توان مورد نيازش را تامين نمايد؛ اين بدين

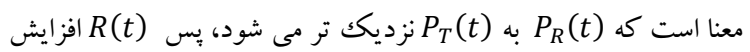

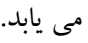

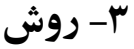

اين يزوهش با هدف كمينه كردن هزينه كل يكك نانوشبكه كه شامل هزينه خريد برق از شبكه توزيع بالادستى، هزينه عملكرد هر يكك از اجزاء

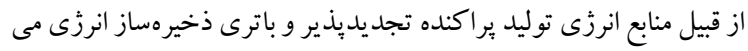

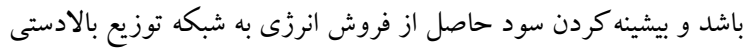

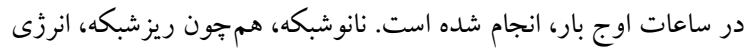

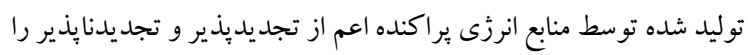

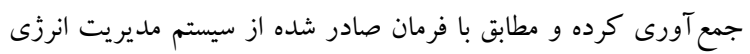

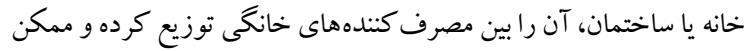


ساز متصل شده به آن قابليت شارز يا دشارز انرزى را در زمانهاى

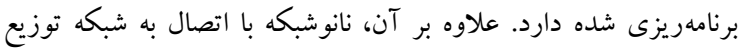
بالادستى، امكان تبادل توان دو طرفه دارد.

ع-1- مدل سازى خريد و فروش

هدف از باسخكويى بار تنها مصرف برق كمتر درو در ساعات بيك

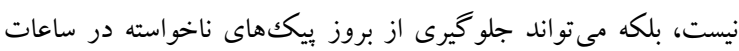

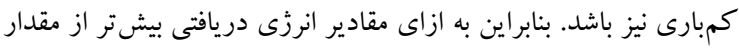

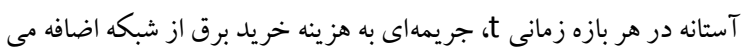
شود كه از رابطهى زير بهدست مى آيد [بr]:

$$
\left(P_{t}^{\text {grid,buy }}-P_{\mathrm{thr}}^{\text {peak }}\right) \cdot \delta \cdot p d P
$$

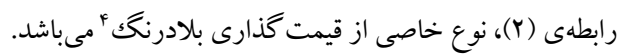

\section{ع-r- مدل سازى توربين بادى}

براى مدل سازى بخش مربوط به توان تورين بادى تورين بادى از تابع احتمالاتى

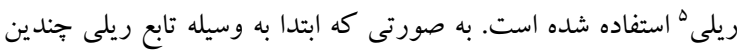

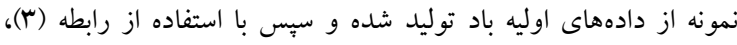

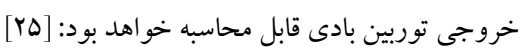
$P_{w}(v)=\left\{\begin{array}{lc}0 & , 0 \leq v_{a w} \leq v_{c i} \\ P_{\text {rated }} \times \frac{\left(v_{a w}-v_{c i}\right)}{\left(v_{r}-v_{c i}\right)}, P_{\text {rated }} & v_{r} \leq v_{a w} \leq v_{c o}, v_{c i} \leq v_{a w} \leq v_{r} \\ 0 & , v_{c o} \leq v_{a w}\end{array}\right.$

ع-r-r- مدل سازى ينل خورشيدى

در اين بخش نيز مانند توليد توان بادى، ابتدا به وسيله تابع بتا دادههاى

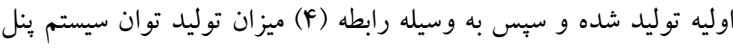

خورشيدى قابل محاسبه خو اهد بود [roا

$$
P_{P V}(s i)=\eta^{P V} \times S^{P V} \times s i \quad(k w)
$$

\section{ع-ع- مدلسازى ذخيرهساز و خودرو الكتريكى}

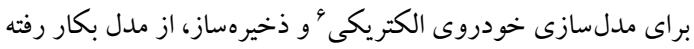

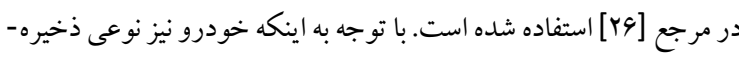

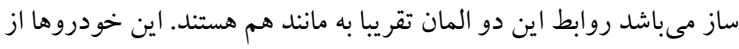

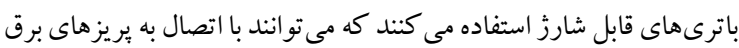

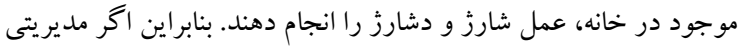

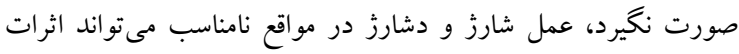

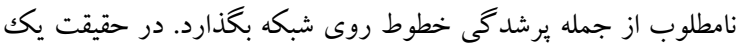

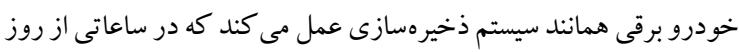

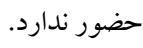

در شبكه بالادستى دادههاى مربوط به قيمت برق براى يك روز

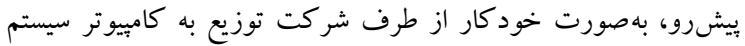

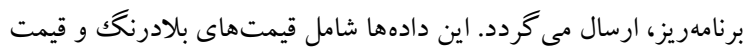

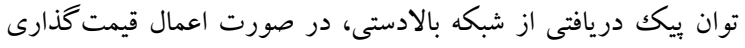

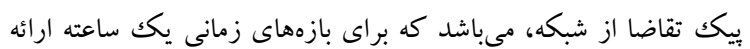

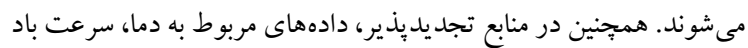

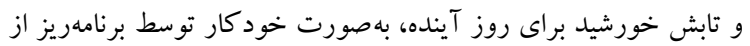

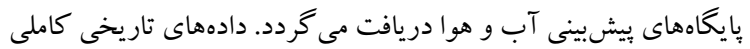

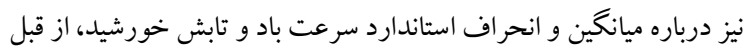

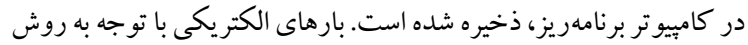

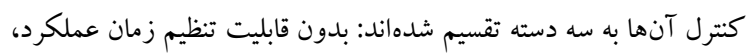

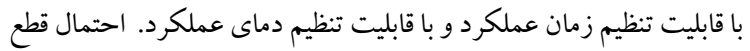

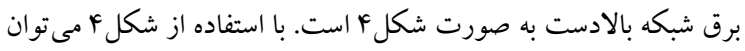

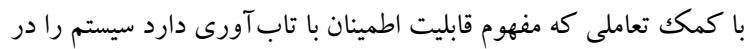
تمامى ساعات روز با هدف تاب آورتر كردن، بهينه كرد.

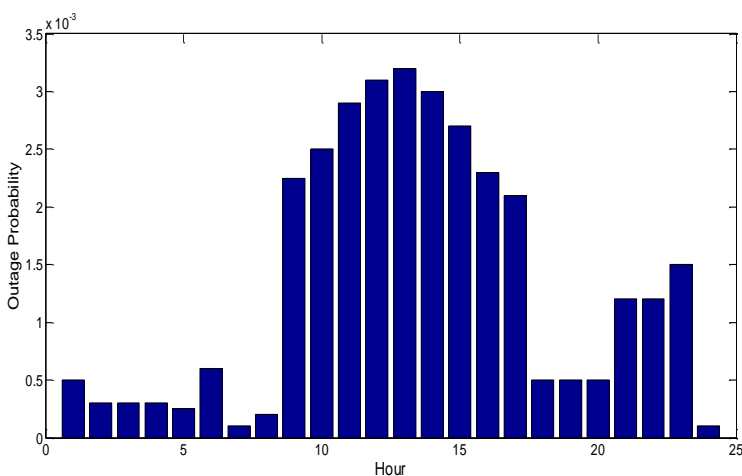

شكل ٪: احتمال قطع برق براى هر ساعت در يكك روز نمونه [rT]

\section{r-r-r- هدف يثوهش}

هزينه كل عملكرد نانوشبكه در اين يُزوهش را مى توان بون به دو قسمت

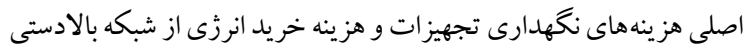

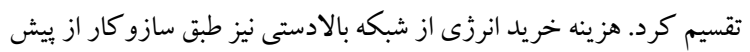

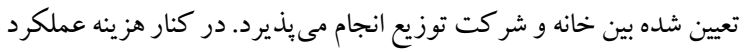

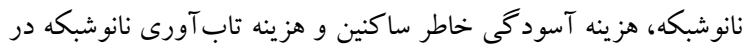

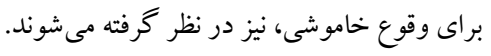

كمينه سازى:

هزينه آسودگىخاطر ساكنين+ هزينه تابآورى انرزى + هزينه

عملكرد نانوشبكه

\section{ع- مدل سازى}

نانوشبكه در نظر گرفته شده در اين يزوهش مجهز به شبكهاى است

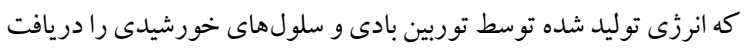

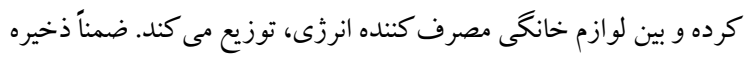


بازه را نشان مى دهد. اما دسته سوم لوازم برقى با تنظيم دمايى مىباشند كه با تنظيم دما مى توان مصرف برق را كنترل كرد. اين وسايل شامل سيستم

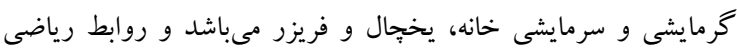

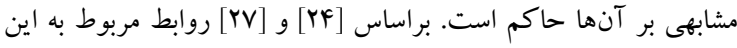
دسته وسايل به صورت زير است.

$$
\begin{aligned}
& O S_{t}^{\text {cooler }}=\left\{\begin{array}{c}
1, \theta_{t}^{\text {room }}>\theta_{t}^{\text {set.cooler }} \\
0, \theta_{t}^{\text {room }} \leq \theta_{t}^{\text {set.cooler }}-\theta_{m \text { arg } i n} \\
O S_{t-1}^{\text {cooler }}, \text { otherwise }
\end{array}\right. \\
& \theta_{t}^{\text {room }}=\theta_{t-1}^{\text {room }}+k_{\text {th }}^{\text {room }} \cdot\left(\theta_{t-1}^{\text {amb }}-\theta_{t-1}^{\text {room }}\right) \\
& +k_{\text {human }} \cdot n_{\text {occupants }}(t-1) \cdot\left(\theta_{\text {human }}-\theta_{t-1}^{\text {room }}\right) \\
& +k_{\text {cooler }}^{\text {eff }} \cdot \theta_{\text {cooler }}^{g} \cdot O S_{t-1}^{\text {cooler }} \\
& P_{t}^{\text {demand.cooler }}=O S_{t}^{\text {cooler }} \cdot P^{\text {cooler }}
\end{aligned}
$$

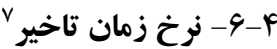

براى نمايش رياضى آسايش ساكنين طبق [YY] يكك رابطه در نظر

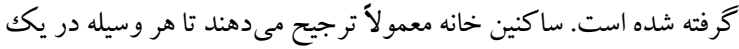

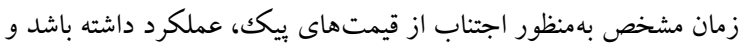

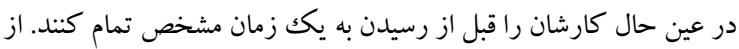

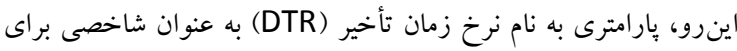

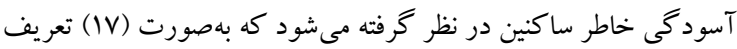

مى گردد [r/

$$
D T R_{j}=\frac{t_{j}^{s t a r t}-t_{j}^{E S t}}{\left(t_{j}^{L F}-t_{j}^{O D}\right)-t_{j}^{E S t}}
$$

$$
\text { از آنجايى كه پارامتر تأخير بزر كتر از الاست، }
$$

نمايى با افزايش DTR

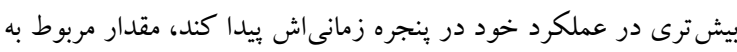

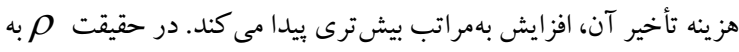

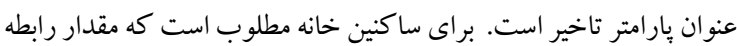
(IN) تا جايى كه ممكن است و منافع مادى آنها را به خطر نمى اندازد،

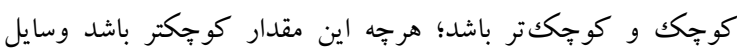

$$
\sum_{j \in J} \rho^{D T R_{j}}
$$

\section{ع- توليد سناريو براى در نظر كيرى نايقينى}

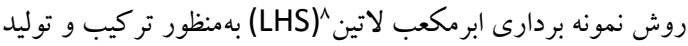

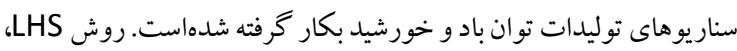

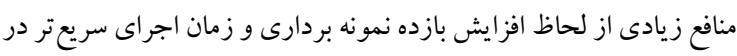

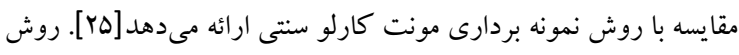

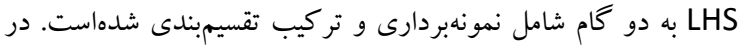
مرحله نمونهبردارى .... نمونه براى نشان دادن طبيعت تصادفى سرعت

$$
\begin{aligned}
& 0 \leq P_{t}^{P E V, c h} \leq P_{P E V, c h}^{\max } \\
& 0 \leq P_{t}^{P E V, d c h} \leq P_{P E V, d c h}^{\max }
\end{aligned}
$$

$P_{t}^{P E V}=\frac{P_{t}^{P E V, d c h}}{\eta_{P E V}^{d c h}}=P_{t}^{P E V, c h} \cdot \eta_{P E V}^{c h}$

$$
S O C_{t+1}^{P E V}=S O C_{t}^{P E V}+\delta \cdot \eta_{P E V}^{c h} \cdot P_{t}^{P E V, c h}
$$$$
-\delta \cdot P_{t}^{P E V, d c h} / \eta_{P E V}^{d c h}-D_{t}^{P E V} \cdot C_{P E V}
$$

$$
S O C_{P E V}^{\min } \leq S O C_{t}^{P E V} \leq S O C_{P E V}^{\max }
$$

براى يكك خودروى الكتريكى، زمان خروج و ورود آن و ميزان

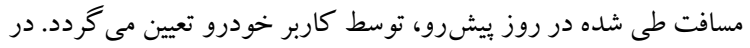

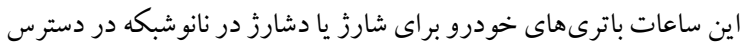

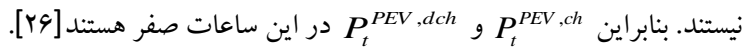
بارامترهاى ذخيرهساز خودرو مشابه با بارامترهاى ذخيرهساز تعبيه شده در

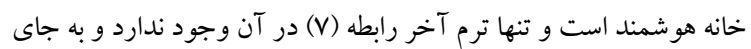
آن رابطه حرارتى سيستم ذخيرهساز درنظر گرفته مى هودود.

ع-0- مدلسازى مصرف كنند كان انرخى در خانه

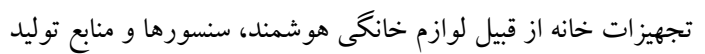
ير اكنده از طريق يكك شبكه محلى خانكى به هم متصل و مرتبط شدهاند.

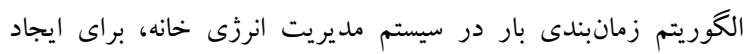

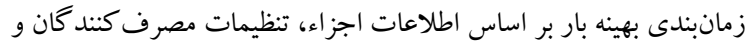

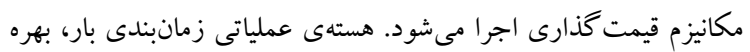

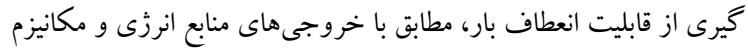

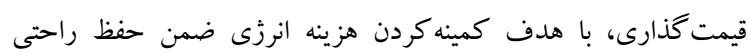
مصرف كنند كان مىباشد. سه دسته وسايل شامل لوازم غير قابل برنامه - رئه

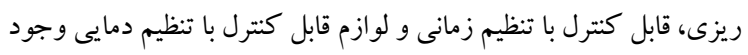

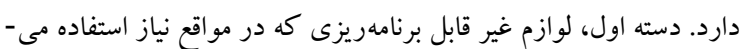

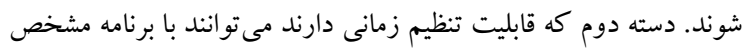

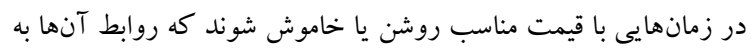
صورت زير مىباشد.

$$
\begin{aligned}
& O S_{t, j}=\left\{\begin{array}{lc}
\mathrm{O} & \text { or } 1 \quad, t_{j}^{E S t} \leq t \leq t_{j}^{L F} \\
\mathrm{O}, & \text { otherwise }
\end{array}\right. \\
& O S_{t, j}=\left\{\begin{array}{l}
1, t_{j}^{\text {start }} \leq t \leq t_{j}^{\text {start }}+t_{j}^{O D}-1 \\
0, \text { otherwise }
\end{array}\right. \\
& P_{t, j}^{s c h}= \begin{cases}P_{j}, & O S_{t, j}=1 \\
\mathrm{O}, & O S_{t, j}=\mathrm{O}\end{cases} \\
& P_{t}^{\text {demand.sch }}=\sum_{j=1}^{J} P_{t, j}^{s c h}
\end{aligned}
$$

معادله (•1) بيان مى كند كه هر وسيله تنها در محدودهى زمانى مشخص خود، يعنى بنجره زمانى اش مى تواند عملكرد داشته باشد. معادله

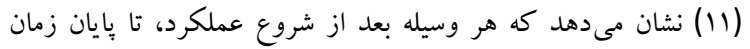

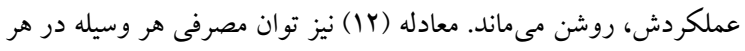




\section{0- فرمولبندى رياضى مساله}

در اين يثوهش با استفاده از روابط مربوط به تابع هزينه كه در بخش بعدى قابل مشاهده است و به وسيله روش بهينه سازى بهبوديافته الكوريتم

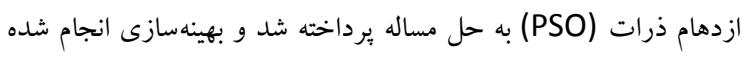

\section{0- 1 - تابع هدف نهايى مساله}

تابع هدف بهينهسازى نهايى ، مجموع وزندار سه تابع هزينه تعريف شده است. همجنين قيود نيز بايد رعايت شوند تا بهترين باسخ يافته شود. $\min : w_{1} \cdot F_{1}(N O C)+w_{2} \cdot F_{2}(D T R)+w_{3} \cdot F_{3}($ EENS $)$ كه در آن 1 ك رابطه (•Y)، توابع هزينه و ميزان تأثير گذارى آنها را بر تابع هدف نهائ نهايى تعيين مى كنند.

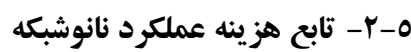

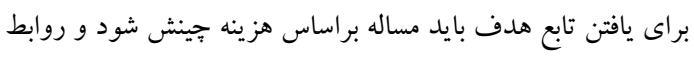

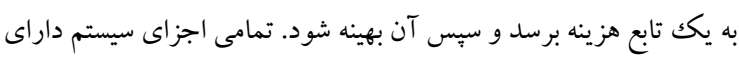

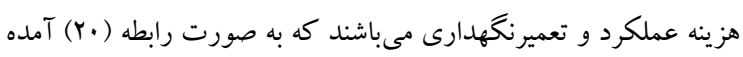

$$
\text { است كه به دلار مىباشد. }
$$

$$
\begin{aligned}
& \text { NOC }=\sum_{t=1}^{T}\left[\begin{array}{l}
\delta\left(m^{w t} P_{t}^{w t}+m^{p v} P_{t}^{p v}\right. \\
+m^{\text {batt }} P_{t}^{\text {batt }}+b_{t} P_{t}^{\text {grid }, \text { buy }} \\
\left.-q_{t} P_{t}^{\text {grid }, \text { sell }}\right)
\end{array}\right] \\
& +\sum_{s=1}^{S} \pi_{s}\left\{\sum_{t=1}^{T}\left[\delta\left(\begin{array}{l}
m^{w t} P_{s, t}^{w t}+m^{p v} P_{s, t}^{p v} \\
+m^{\text {batt }} P_{t}^{\text {batt }}+b_{t} P_{s, t}^{\text {grid }, \text { buy }} \\
-q_{t} P_{s, t}^{\text {grid }, \text { sell }}
\end{array}\right)\right]\right\}
\end{aligned}
$$

كه شامل هزينه عملكرد توربين باترى به ازاى ميزان توليد توان، هزينه

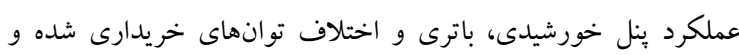
فروخته شده از /به شبكه مىباشد.

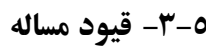

قيود اين مساله از دو قسمت اساسى تشكيل مى مودد: قيود عملكرد

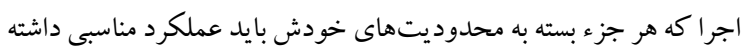

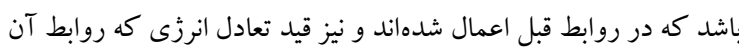
به صورت (YO) مىباشد. همجنين

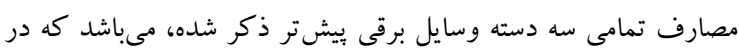
رابطه (Y) بيان كرديده است.
باد و تابش خورشيد توليد شدهاست. براى اين هدف تابع توزيع تجمعى

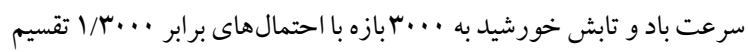

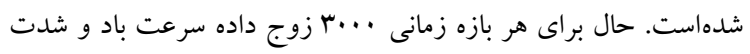

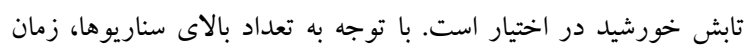

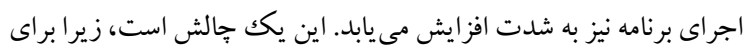

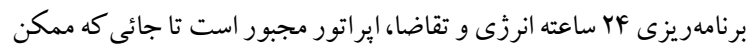

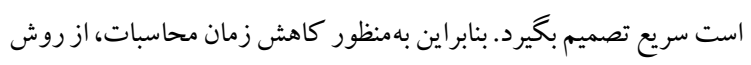

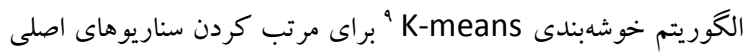
سرعت باد و تابش خورشيد داخل دستههايى بر اساس تشابه و فاصله بين

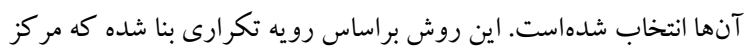

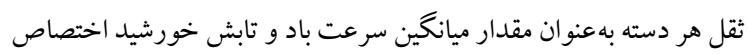

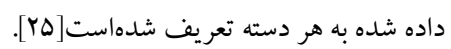

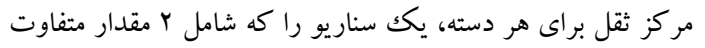
مثلاً مقادير ميانگين سرعت باد و تابش خورشيد است، نشان مى مهدد.

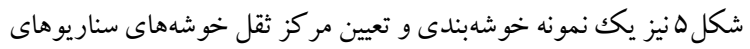

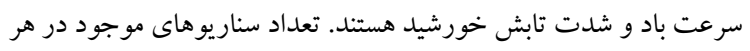
دسته تقسيم بر تعداد كل سناريوهاى اصلى، احتمال هر سناريو رانشان

مى دهد.

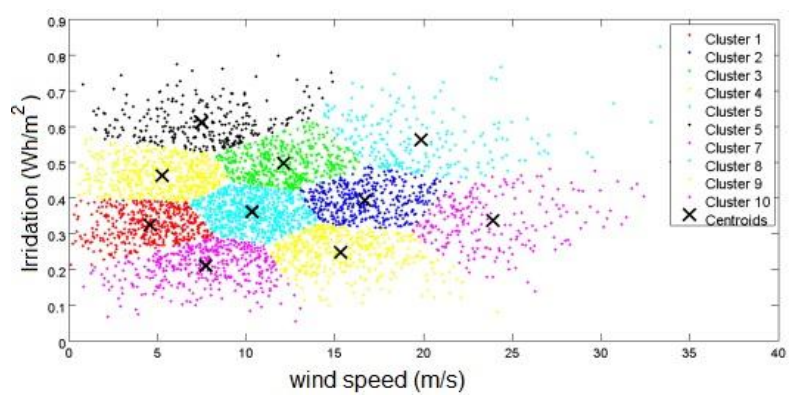
شكل ه: سناريوهاى سرعت باد و تابش خورشيد و خوشهبندى آنها براى ساعت

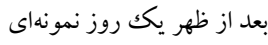

ع-1- فرمولبندى تاب آورى با توجه به [19]، با درنظر گيرى تعريف و وابورى مفهوم تاب آورى ذكر شده،

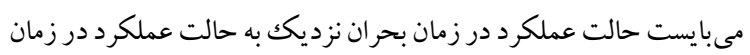

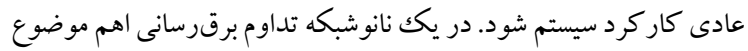
است كه به وسيله اين كار با درنظر كرفتن شاخص انتظار انرزى تأمين نشده

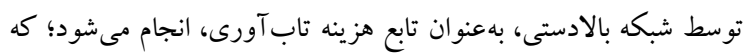

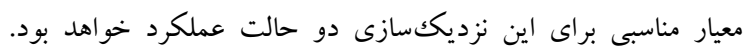
EENS' . شاخص انتظار انرزى تأمين نشده توسط شبكه بالادستى است.

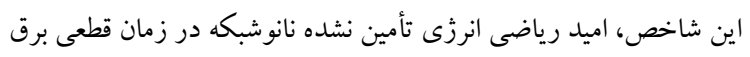

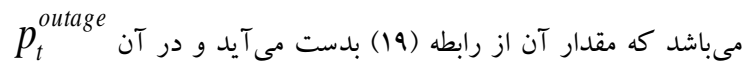
احتمال قطع برق (نايايايى شبكه بالادستى) در هر بازه زمانى است: EENS $=\sum_{t=1}^{T} \delta\left(p_{t}^{\text {outage }} \times P_{t}^{\text {grid }, \text { buy }}\right)(k w h)$ 
هزينه بهتر بودند، بررسى مىشود. هر يكك حالتهاى شبيهسازى در اين

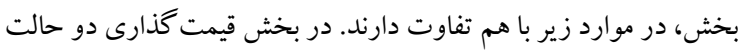

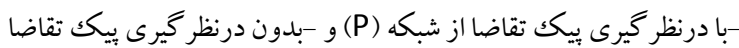

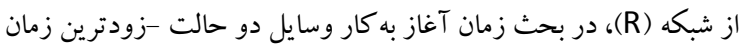

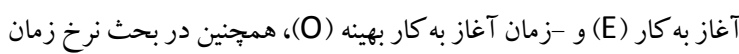

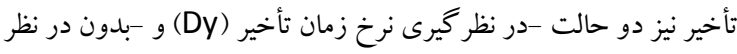

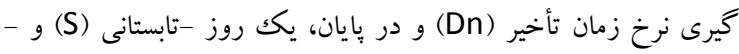

$$
\text { زمستانى (W) مطالعات انجام شده است. }
$$

r-r- مقايسه تعادل توان در حالات مختلف

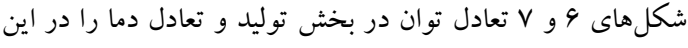

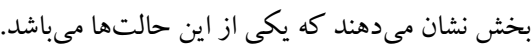

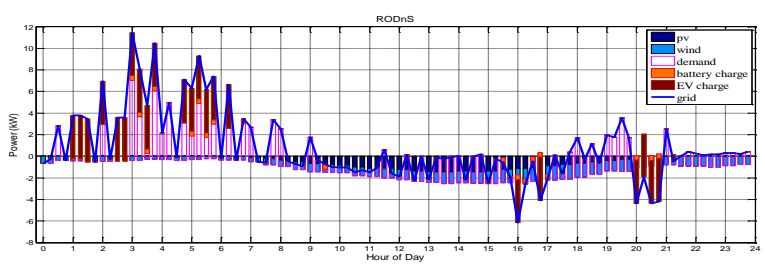

شكل 9: نمودار تعادل توان الكتريكى براى حالت RODnS(بدون درنظر گيرى

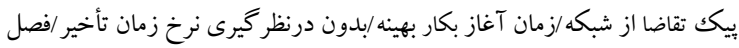
تابستان)

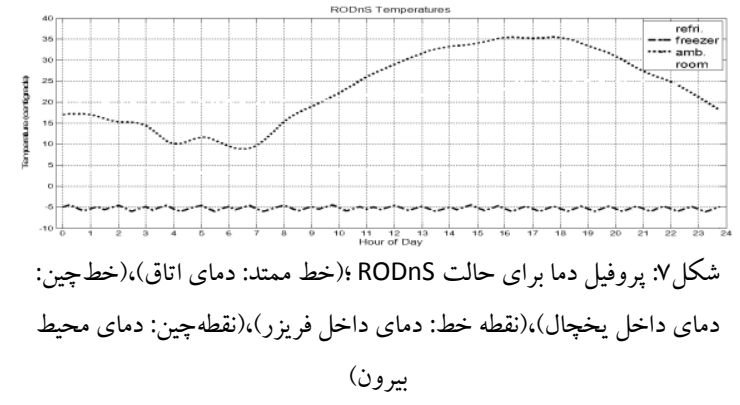

منحنى توان الكتريكى دريافتى از شبكه بالادستى در نمودارهاى تعادل

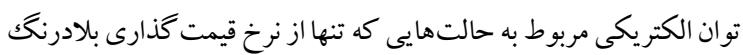

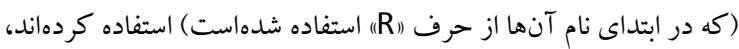
داراى افت و خيزهاى فراوان است زيرا در اين حالتها، زمانبندى وسايل

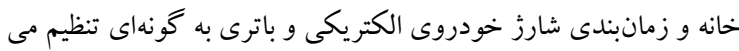

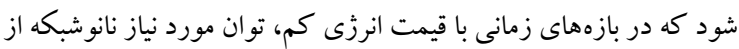

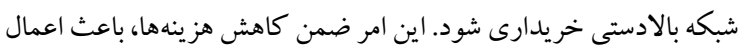

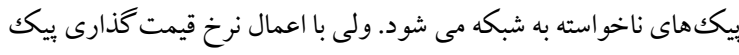

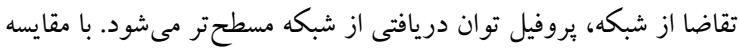

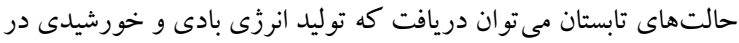

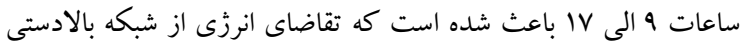

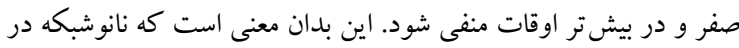
اين ساعات با فروش برق به شبكه در حال سودآورى است. در كنار آن

$$
\begin{aligned}
& P_{t}^{\text {demand }}=P_{t}^{w t}+P_{t}^{p v}+P_{t}^{\text {grid ,buy }} \\
& +P_{t}^{\text {batt }, d c h}-P_{t}^{\text {grid , sell }}-P_{t}^{\text {batt ,ch }} \\
& +P_{t}^{P E V, d c h}-P_{t}^{P E V, c h}, \quad \forall t \\
& P_{t}^{\text {demand }}=P_{t}^{\text {demand , non_sch }}+P_{t}^{\text {demand }, \text { sch }} \\
& +P_{t}^{\text {demand .cooler }}+P_{t}^{\text {demand.heater }} \\
& +P_{t}^{\text {demand.refri }}+P_{t}^{\text {demand freezer }}
\end{aligned}
$$

\section{0-ع- نرماليزهسازى}

براى اين كه تابع هزينه بتواند وارد تابع هدف بهينه سازى شوده، بايد

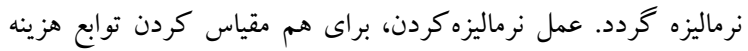

$$
\text { موجود در تابع هدف نهايى انجام مىشود. }
$$

$$
\begin{aligned}
& F_{1}(N O C)=\frac{N O C}{N O C_{\text {max }}} \\
& F_{2}(D T R)=\frac{\sum_{j \in J} \rho^{D T R_{j}}}{\left(\sum_{j \in J} \rho^{D T R_{j}}\right)_{\max }} \\
& F_{3}(E E N S)=\frac{E E N S}{(E E N S)_{\max }}
\end{aligned}
$$

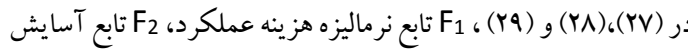
سا كنين و F3 نرماليزهشده تاب آورى مىباشد.

\section{7- نتايج شبيهسازى}

در اين بخش به ارايه نتايج و تفسير نتايج شبيهسازى برداخته مى شود.

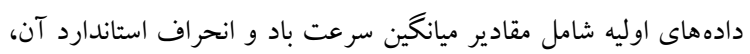

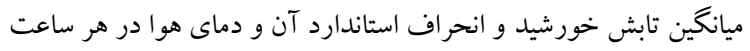

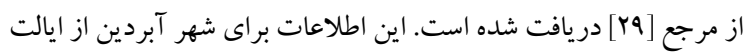

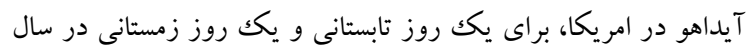

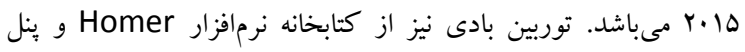

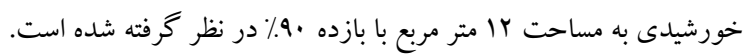

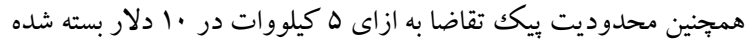

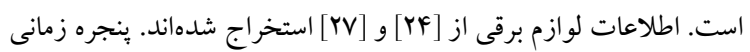
ها دقيقهاى مىباشد و روند بهينه سازى به روش حالت ابتكارى ازدحام

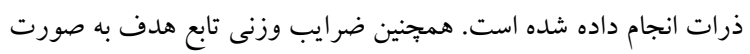

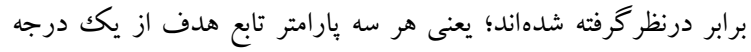

$$
\text { اهميت برخوردار هستند. }
$$

7- - حالتهاى مطالعه با توجه به روش قيمت گذذارى، زمان آغاز به كار وسايل، نرخ زمان

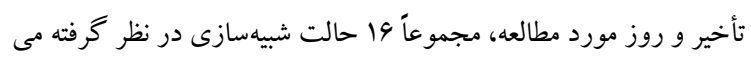
شود. ابتدا نتايج بدون درنظر گرفتن تابع هزينه تاب آورىى، بدست آمده،

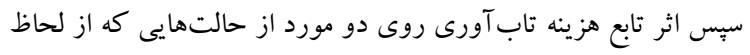


7-ع- بررسى اثر درنظر يرى ثاب آورى روى دو حالت PODyS و RODnS

براى بررسى اثر شاخص تاب آورى بر نتايج حاصل از شبيهسازى، شبيه

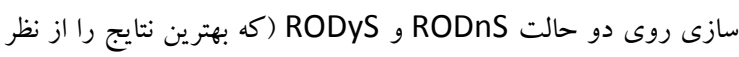

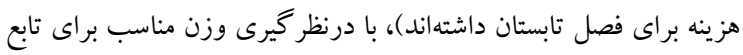

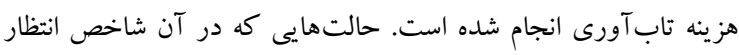

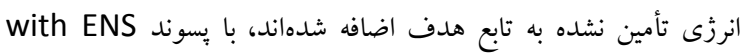

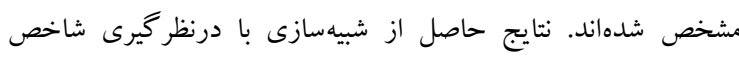
تاب آورى در جدول آورده شده است. در اين جدول هزينه عملكرد

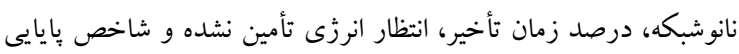
انرزى مورد مقايسه قرار خر فتهاند.

\begin{tabular}{|c|c|c|c|c|c|}
\hline $\begin{array}{c}\text { شاخص بايايى } \\
\text { EIR } \\
\text { انرزى }\end{array}$ & $\begin{array}{l}\text { كل انرزى } \\
\text { تأمين نشده } \\
\text { (KIVh) }\end{array}$ & 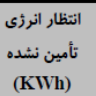 & زمان تأخير & نانوشيكرد & ن ن ام حالت \\
\hline ./१११५०४ & rg/IYM &.$/ . r y f$ & rr/q &.$- / 9 \cdot 18$ & RODnS \\
\hline ./१११५१० & rg/rAsG & . /rr. & ./Qr &.$/$ orr & RODyS \\
\hline ./११९९८. & $f \cdot / r f r q$ &.$/ .1 \% 9$ & $10 / 9 r^{\prime}$ & . /GTST & RODnS_with ENS \\
\hline ./१९९९ाf & ri/rva. &.$/ .|r|$ & $r / Y A$ & 1/ovor & RODyS_with ENS \\
\hline
\end{tabular}

جدول ا: مقايسه نتايج حاصل از شبيهازى با درنظر گيرى شاخص تاب آورى و و بدون درنظر كيرى شاخص تاب آورى براى حالتهاى RODNS و RODS

نتايج حاصل از جدول ا نشان مىدهد كه با در نظر گرفتن شاخص مربوط به انتظار انرزى تأمين نشده و اضافه كردن آن به عنوان تان تابع هزينه

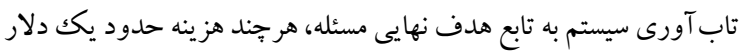

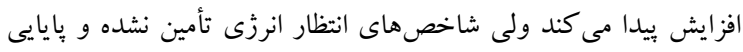

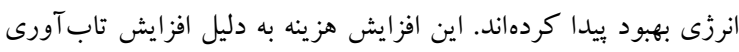
است. در حالت تاب آور عملكرد سيستمهاى ذخيره سنگين تر شده و نياز

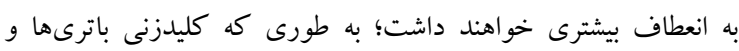

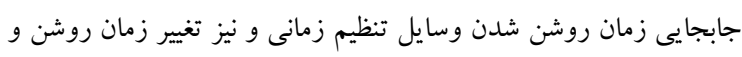

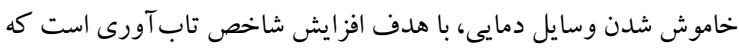

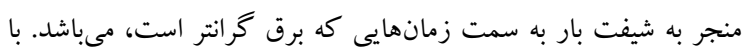

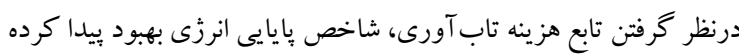

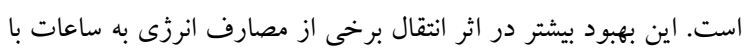

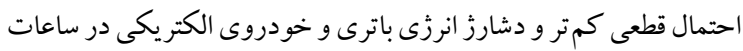

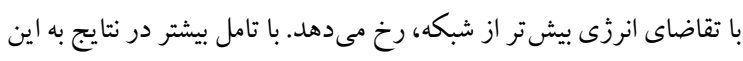
مهم دست ميابيم كه كم ترين هزينه مربوط به حالت RODnS است، زئ زيرا

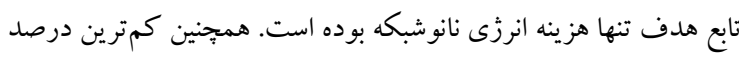

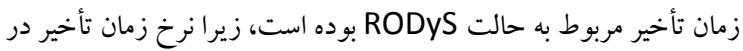

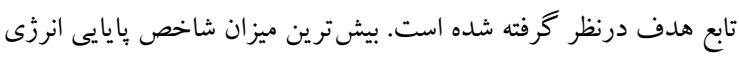

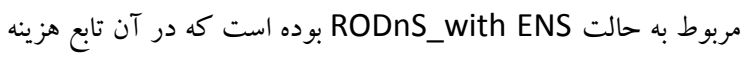
تاب آورى نيز در تابع هدف نهايى مسأله درنظر گرفته شده است.
انتقال بارهاى موجود در خانه از اين ساعات به ساعات ديخر به اين امر

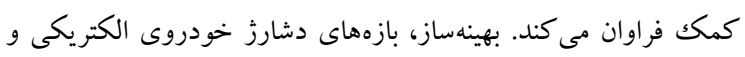

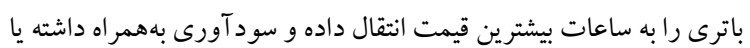
از هزينها مى كاهد.

\section{7-r-r- مقايسه تمام حالتها از نظر هزينه، وِيك توان، درصد}

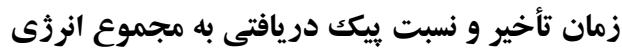

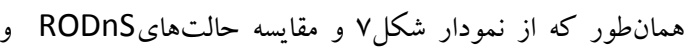

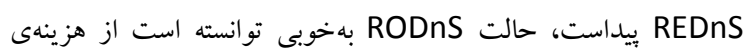
نانوشبكه بكاهد. منفى شدن ميلهى مربوط به هزينه در حالت RODnS

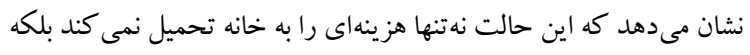
اندكى سود نيز به همر اه دارد. در عين حال در اين حالت مقدار درصد زمان آنسان تأخير آن و نيز بيكك تقاضاى توان از شبكه نسبت به ساير حالتها، داله بالاتر

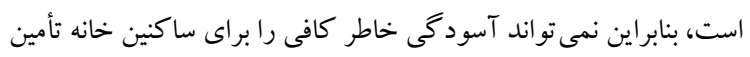

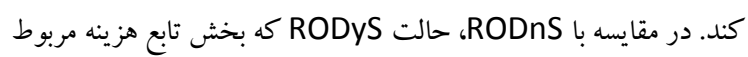

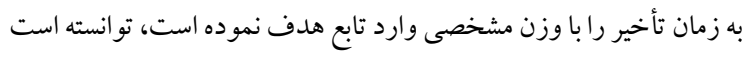

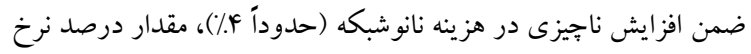

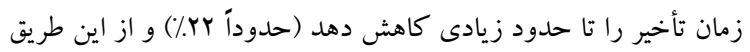

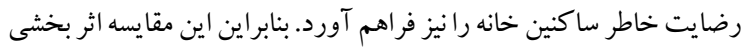

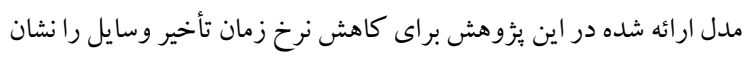

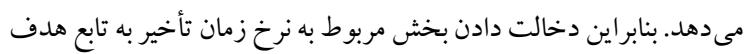

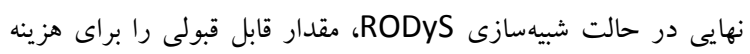

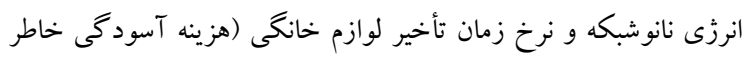

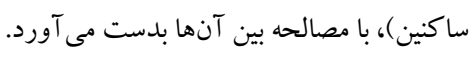

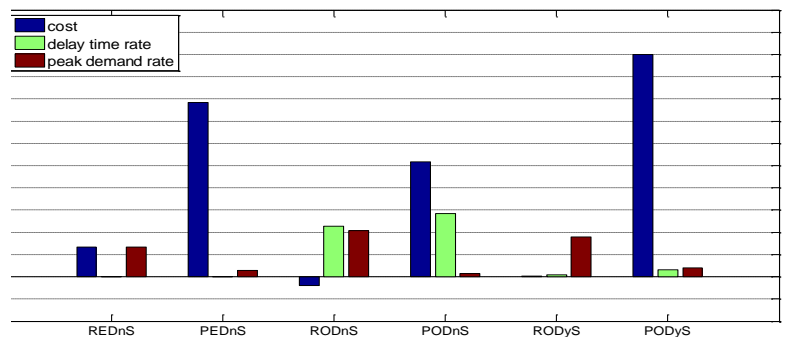

شكل من نمو دار مقايسه اى بين هزينه(ستون آبى)، نرخ زمان تأخير (ستون سبز) و

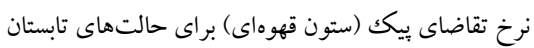

مقايسه بين حالتهاى RODnS و PODnS، و حالتهاى PODYS م RODSS PODyS و حالتهاى REDnS و REDnS بهترتيب كاهش وهاى 19 19، ها و ال ادرصدى را در ميزان بيكك انرزى دريافتى از شبكه نشان مى دهد

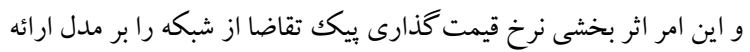

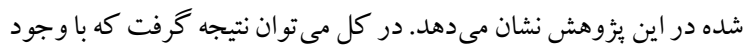

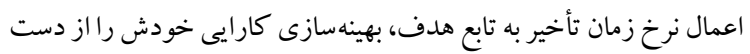

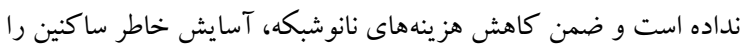
با كم كردن درصد زمان تأخير وسايل فراهم مى كند. 


\section{مراجع}

[1] Vc. Gungor, D. Sahin, T. Koack, S. Ergut.C. Bucella, C. Cecati, and G. P. Hancke, "Smart Grid and Smart Homes Key Players and Pilot Projects", IEEE Industrial Electronics magazine, December 2012.

[2] Momoh, J., "Smart grid design for efficient and flexible power networks operation and control",In Power Systems Conference and Exposition, PSCE'09. IEEE/PES, March2009.

[3] H. Morsali, S. M. Shekarabi, K. Ardekani, H. Khayami, A. Fereidunian, M. Ghassemian, H. Lesani., "Smart Plugs for Building Energy Management System", 2nd Iranian Conf. on Smart Grid, ICSG 2012.

[4] M. Kojury-Naftchali, A. Fereidunian, H. Lesani, "Identifying susceptible consumers for demand response and energy efficiency policies by timeseries analysis and supplementary approaches", 24th Iranian Conf. on Elec. Engineering, ICEE 2016.

[5] Ghasemieh H, Haverkort BR, Jongerden MR, Remke A. Energy resilience modelling for smart houses. In2015 45th Annual IEEE/IFIP International Conference on Dependable Systems and Networks 2015 Jun 22 (pp. 275-286). IEEE.

[6] Ouyang, M., \& Dueñas-Osorio, L. (2014). Multidimensional hurricane resilience assessment of electric power systems. Structural Safety, 48, 1524.

امينى فر. فرخ، "درآمدى بر مفهوم تابآورى در سيستمهاى

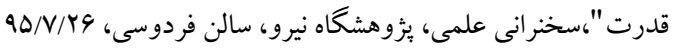

[8] Roche R, Berthold F, Gao F, Wang F, Ravey A, Williamson S. A model and strategy to improve smart home energy resilience during outages using vehicle-to-home. InElectric Vehicle Conference (IEVC), 2014 IEEE International 2014 Dec 17 (pp. 1-6). IEEE.

[9] Marrone S, Gentile U. Finding Resilient and Energy-saving Control Strategies in Smart Homes. Procedia Computer Science. 2016 Dec 31;83:976-81.

[10] Guan, X., Xu, Z. and Jia, Q.S.,"Energy-Efficient Buildings Facilitated by Microgrid," IEEE Transaction on Smart Grid, Vol. 1, No. 2, pp. 243$252,2010$.

[11] Huang, Y., Tian, H. and Wang, L., "Demand response for home energy management system,"

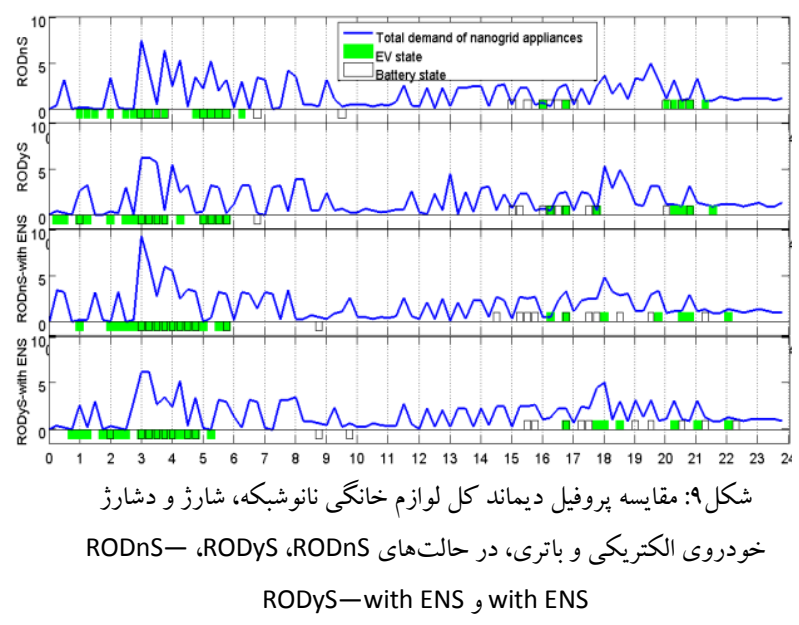

شكل 9، ديماند كل لوازم خانكى نانوشبكه، وضعيتهاى شارز و دشارز خودروى الكتريكى و باترى را در هر يكك از جهار حالت بالا نشان

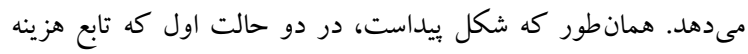

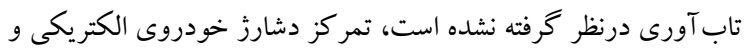

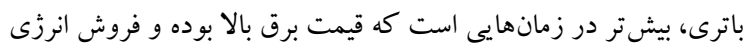

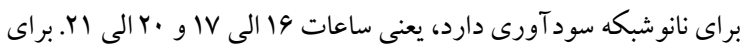

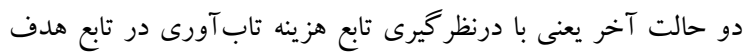

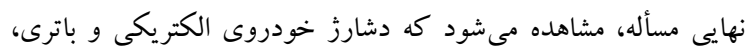

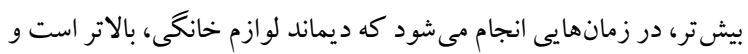

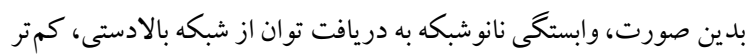

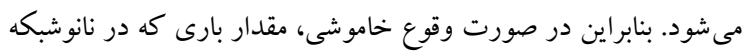

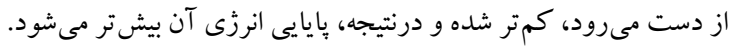

\section{Y- تحليل و نتيجه كيرى}

$$
\begin{aligned}
& \text { اين بثزوهش اثر برنامهريزى در زمانبندى و سيستم دمايى رابا مقايسه }
\end{aligned}
$$

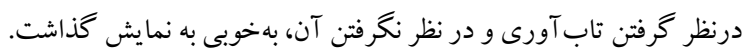

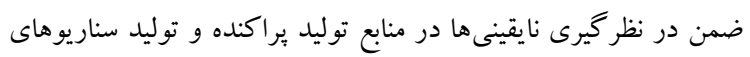

$$
\begin{aligned}
& \text { مختلف به روشهاى جديد بهترين حالات را در سناريوسازى انجام داده و } \\
& \text { به تابع هدف نهايى وارد شود. همجنين به زمانهاى بهينه شارزو دشارز }
\end{aligned}
$$

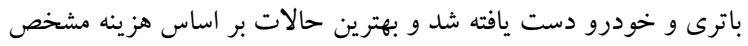

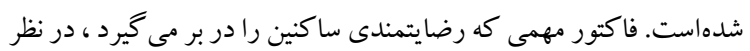

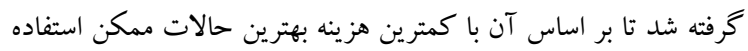

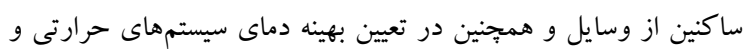

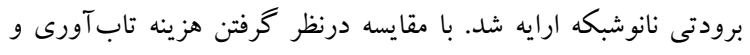

$$
\begin{aligned}
& \text { درنظر نغرفتن آن مشاهده مىشود كه با وجود افزايش كمى درو در هزينه، }
\end{aligned}
$$

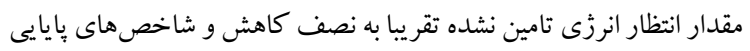

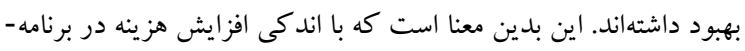

$$
\begin{aligned}
& \text { ريزى مى توان از هزينهاى اضافى در آينده جلو گيرى كرد. }
\end{aligned}
$$


سعيد باقرى، حسين طالبى، عليرضا فريدونيان

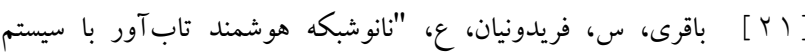

$$
\begin{aligned}
& \text { مدير يت انرزى خطى و درنظر گيرى عدم قطعيت" ششمين كنفر انس بين }
\end{aligned}
$$

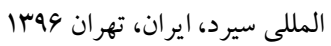

[22] Clark-Ginsberg. A, Stanford University, "What's the Diffrence between Reliability and Resilience", Online: https://ics-cert.uscert.gov/sites/default/files/ICSJWG-

Archive/QNL_MAR_16/reliability\%20and\%20r esilience\%20pdf.pdf , March 2017.

$$
\begin{aligned}
& \text { ليموزاده، ا.، درخشنده، س.، ى.، (برنامهريزى همزمان انرزى و ذخيره }
\end{aligned}
$$

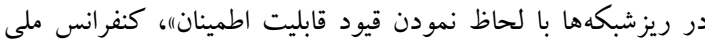

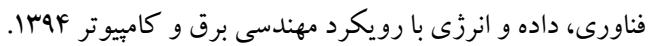

[24] Zhang, Di, Nilay Shah, and Lazaros G. Papageorgiou. "Efficient energy consumption and operation management in a smart building with microgrid." Energy Conversion and management 74 (2013): 209-222.

[25] Mazidi, M., Zakariazadeh, A., Jadid, S. and Siano, pp.,"Integrated scheduling of renewable generation and demand response programs in a microgrid," Energy Conversion and Management, Vol. 86, pp. 1118-1127, 2014.

[26] Rastegar, M., Fotuhi-Firuzabad, M. and Aminifar, F., and Farrokh Aminifar. "Load commitment in a smart home." Applied Energy, Vol. 96, pp. 4554, 2012.

[27] Tarasak, pp., Chai, C.C., Kwok, Y.S. and Oh, S.W., "Demand Bidding Program and Its Application in Hotel Energy Management." IEEE Transactions on Smart Grid, Vol. 5, No. 2, pp. 821-828,2014.

[28] Zhao, Z., Lee, W.C., Shin, Y. and Song, K.B., "An Optimal Power Scheduling Method for Demand Response in Home Energy Management System," IEEE Transactions on Smart Grid, Vol. 4, No. 3, pp. 1391 - 1400, 2013.

[29] AgriMet, “AgriMet Weather Data." [Online]. Available:

http://www.usbr.gov/pn/agriment/wxdata.html

Electrical vehicle

7 Delay time rate

${ }^{8}$ Latin Hypercube Sampling

${ }^{9}$ K-means clustering

${ }^{10}$ Exception of energy not supplied
International Journal of Electrical Power \& Energy Systems, Vol. 73, pp. 448-455, 2015.

$$
\text { انوحمد خليل زاده، عليرضا فريدونيان، سيدمحمد تقى بطحايى، "خانه }
$$

[13] M. H. Amrollahi, S.M.T. Bathaee, A. Fereidunian, A. Bahramiazar, "Integration of Renewble Energy Sources in Zero Energy Biuldings", Conf. and exhibition on Elec. Distribution Cired, 2014.

[14] Shirazi, E., Zakariazadeh, A. and Jadid, S.,"Optimal joint scheduling of electrical and thermal appliances in a smart home environment," Energy Conversion and Management, Vol. 106, pp. 181-193, 2015.

[15] Chakraborty, S., Weiss, M.D. and Simoes, M.G.,"Distributed intelligent energy management system for a single-phase high-frequency $\mathrm{AC}$ microgrid," IEEE Transactions on Industrial Electronics, Vol. 54, No. 1, pp. 97-109, 2007.

[16] Dukpa, A., Duggal, I., Venkatesh, B. and Chang, L.,"Optimal participation and risk mitigation of wind generators in an electricity market," IET renewable power generation, Vol. 4, No. 2, pp. 165-175, 2010.

[17] Setlhaolo, D. and Xia, X., "Optimal scheduling of household appliances with a battery storage system and coordination," Energy and Buildings, Vol. 94, pp. 61-70, 2015.

[18] Gholami. A, Aminifar. F, Shahidehpour. M, "Frontlines against the Darkness", IEEE Electrification Magazine, 1 march 2016.

[19] Ouyang, M., \& Dueñas-Osorio, L. (2014). Multidimensional hurricane resilience assessment of electric power systems. Structural Safety, 48, 1524.

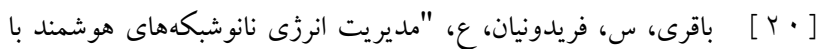

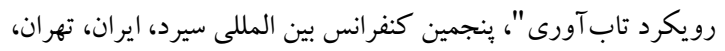

1490

\footnotetext{
1 Demand side management

${ }^{2}$ Energy efficiency (EE)

${ }^{3}$ Demand response (DR)

4 Real time

${ }^{5}$ Rayleigh
} 